\title{
Effect of Fruit Temperature on the Growth of Cucumber Fruits ${ }^{1}$
}

\author{
Akio Tazuke and Ryozo Sakiyama \\ Faculty of Agriculture, University of Tokyo, Bunkyo-ku, Tokyo 113
}

\begin{abstract}
Summary
The effect of fruit temperature on the growth of cucumber fruit at the early stage of development was investigated. Cucumber fruits attached on the vine were put in chambers controlled at temperatures ranging from $5^{\circ}$ to $30^{\circ} \mathrm{C}$.

Relative growth rate (RGR) increased as the fruit temperature was raised to $30^{\circ} \mathrm{C}$, and was estimated to be 0 at about $5^{\circ} \mathrm{C}$. The multiple regressions of RGR on fruit temperature and fruit volume gave high multiple correlation coefficients for different seasons and cultivars. Partial correlation was positive between RGR and fruit temperature and negative between RGR and fruit volume. This indicated that the RGR of fruits at the same volume is almost linearly related to fruit temperature. However, an Arrhenius plot of RGR gave a line with a break point near $12^{\circ} \mathrm{C}$, at which point a qualitative change in fruit growth was suggested to occur.

$\mathrm{Q}_{10}$ of $\mathrm{RGR}$ was about 2 between $15^{\circ}$ and $30^{\circ} \mathrm{C}$ regardless of the growing season, but for fruits at the same temperature, RGR was higher in spring than in winter. From this result it was suggested that a seasonal difference in RGR could be brought about by a difference in carbon concentration of phloem sap, while the influx rate of the phloem sap was determined by fruit temperature.

There was no difference in temperature response of RGR between cultivars.
\end{abstract}

\section{Introduction}

The translocation rate of assimilates from a tomato leaf depends on the sucrose concentration of the leaf $(1,5)$. The rate is enhanced by treatments such as $\mathrm{CO}_{2}$ enrichment which increase the photosynthetic rate of the tomato plant(6). This suggests that the photosynthetic rate can be a limiting factor on fruit growth. On the other hand, the carbon import rate of a tomato fruit responds negatively to fruit size and positively to fruit temperature(16). This means that the carbon import rate of fruit depends on the condition of the fruit itself as well as of the photosynthetic organs. Temperature has been shown to affect sink activity in sink organs including fruit of peas(10) and tomatoes(16) and tap roots of beet(4). However, fewer quantitative studied have been made of growth in sink organs than

\footnotetext{
1 Received for publication April 8, 1985.
}

in photosynthetic organs(7).

In cucumber, reproductive and vegetative growth proceed simultaneously. In order to obtain a high yield, assimilates must be partitioned properly between vegetative parts and fruits. This is particularly important in greenhouse cultivation during the winter, when the quantity of photosynthetic products during the daytime is reduced. There have been many studies on assimilate translocation in fruit vegetables, especially in relation to the control of night temperatures in greenhouse during winter(8). However, few of them examined the role of fruits in the translocation of carbon.

In this study, we tried to clarify the effect of fruit temperature on the assimilate translocation to the fruit. We tried to grow plants under conditions where the supply of assimilates would be sufficient not to limit fruit growth. 


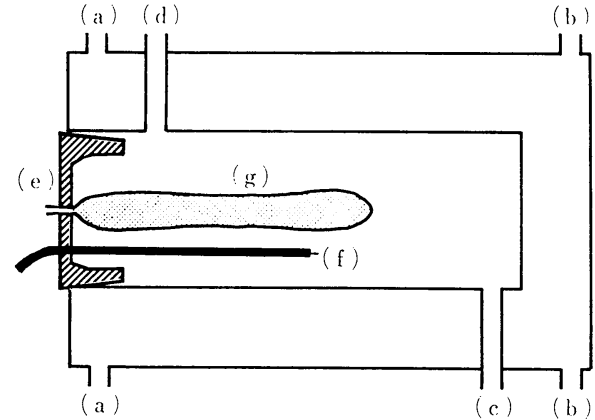

Fig. 1. Diagram of a chamber used to control the temperature of cucumber fruit on vine; (a) water inlet, (b) water outlet, (c) air inlet, (d) air outlet, (e) rubber cap, (f) thermocouple and $(\mathrm{g})$ fruit.

\section{Materials and Methods}

In winter and spring of 1982, cucumber plants (Cucumis sativus L.) of cvs. 'Tokiwa Hikari 3 Go A Gata' and 'Kurume Ochiai H Gata' were grown in a glasshouse. Both cultivars were grafted on to figleaf gourd stock (Cucurbita ficifolia Bouche). Two rows were planted $50 \mathrm{~cm}$ apart on the bed, with $50 \mathrm{~cm}$ between plants. Basal fertilizer was applied to the soil at the recommended rate, and after planting, liquid fertilizer was ap plied at intervals of about 2 weeks. All lateral shoots were removed. The height of plants from the bed was kept at about $2 \mathrm{~m}$ by secuting the top with a hook which was constantly reattached to an upper node as the plants grew. Plants were irrigated every morning. Female floweres were open pollinated, but when fruits did not set well, they were hand-pollinated.

Fruits about $9 \mathrm{~cm}$ in length were used. In order to exclude competition between a treated fruit and the adjacent ones, fruits and female floweres on two upper and lower nodes were removed. Each fruit, as attached on the vine, was put in a doublelayered cylindrical chamber $(6 \mathrm{~cm}$ in internal diameter, $12 \mathrm{~cm}$ in external diameter, $30 \mathrm{~cm}$ in length) made of acrylic acid resin as shown in Fig. 1. The chamber was wrapped in polyurethane foam sheet as an insulator and in aluminium foil to shade it from the light. The opening of the inner tube, into which fruits were put, was sealed with a rubber cap. The cap had a small hole at its centre and a radial cut from the centre to the margin so that the peduncle of the attached fruit could be held through the hole. The inner tube was provided with two vents for air flow, but was not aired in this experiment. The temperature of the chamber was kept constant by circulating temperature-controlled water through the outer space of the chamber. The temperature near the fruit in the chamber, monitored by a thermocouple and recorded continuously, was kept within $0.5^{\circ} \mathrm{C}$ of the required temperature.

The growth in volume of each fruit was determined until it grew to about $20 \mathrm{~cm}$ long. The volumes of several fruits selected from other plants with no temperature control were also measured.

In order to estimate fuit volume nondestructively, fruit volume index (FVI) was computed by

$$
\mathrm{FVI}=l \times\left(\mathrm{a}_{1}{ }^{2}+\mathrm{a}_{2}{ }^{2}+\mathrm{a}_{3}{ }^{2}\right)
$$

where $l(\mathrm{~mm})$ is fruit length and $\mathrm{a}_{1}, \mathrm{a}_{2}$ and $\mathrm{a}_{3}(\mathrm{~mm})$ are the girths at three positions. Fruit volume $\left(\mathrm{cm}^{3}\right)$ was calculated by multiplying FVI by a proportionality constant of $22.61 \times 10^{-6}$, as reported previously (13). Fruit volume was measured once or twice a day. Growth rate per hour (GR) and relative growth rate (RGR) were computed. Fruit temperature was controlled at $5^{\circ}, 10^{\circ}, 15^{\circ}, 20^{\circ}, 25^{\circ}$ and $30^{\circ} \mathrm{C}$ in winter and $15^{\circ}, 20^{\circ}, 25^{\circ}$ and $30^{\circ} \mathrm{C}$ in spring. Measurements were duplicated for each temperature.

In some experiments, fruits were harvested after the treatment and volume, fresh weight and dry weight were determined.

\section{Results}

Fruit volume (Fig. 2 a) increased exponentially with time, GR (Fig. 2 b) increased linearly, and RGR (Fig. $2 \mathrm{c}$ ) declined. As the temperature rose, fruit volume and GR increased more rapidly. The highest GR observed at the end of the $25^{\circ}$ and $30^{\circ} \mathrm{C}$ treatments was comparable with the maximum GR of the fruit grown under uncontrolled conditions in the spring culture, as 

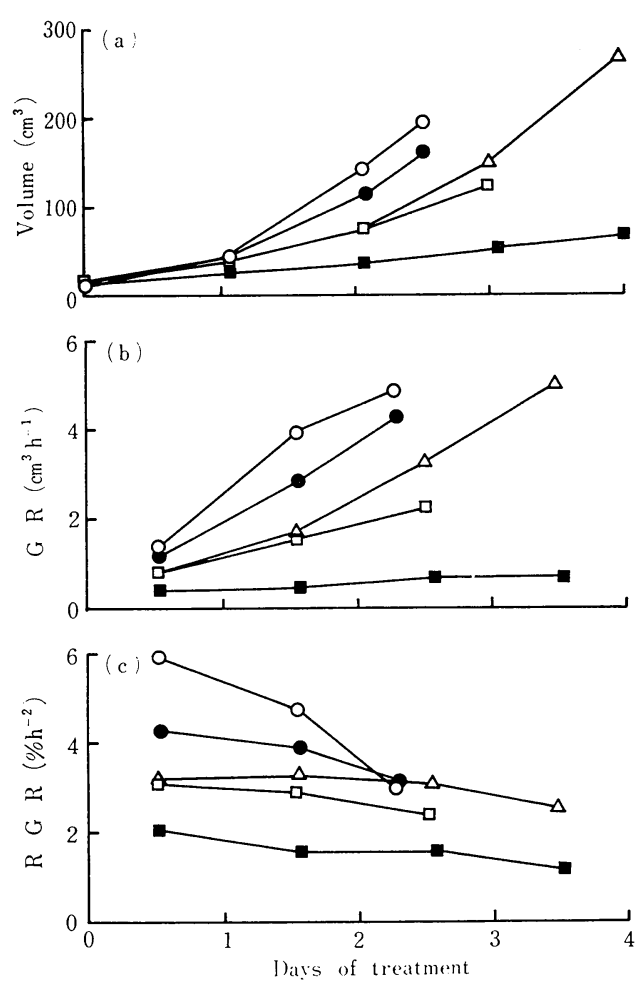

Fig. 2. Changes in (a) growth in volume, (b) GR, and (c) RGR of cucumber fruits, cv. Kurume Ochiai $\mathrm{H}$ Gata grown in a glasshouse in spring. Fruits were held, as attached on vine, at a temperature of $15^{\circ}(\mathbf{\square}), 20^{\circ}(\square), 25^{\circ}(\mathbf{O})$ and $30^{\circ} \mathrm{C}(\bigcirc)$, or under uncontrolled conditions $(\triangle)$.

reported previously(13). RGR was higher at the begining of treatments and declined more rapidly at higher temperatures. RGR of fruit varied less than GR, as previously reported for fruits under uncontrolled temperature conditions(13). The effect of handpollination on GR and RGR was not evaluated, but seemed to be insignificant since variation within each treatment was very small.

Fig. 3 shows the daily means of RGR of fruits during the first day of treatment. At the initial measurement, RGR showed little difference between cultivars, and was linearly related to fruit temperature between $15^{\circ}$ and $30^{\circ} \mathrm{C}$. Even at the same temperature, however, RGR was higher in spring than in winter. At $5^{\circ} \mathrm{C} R G$ was about zero.

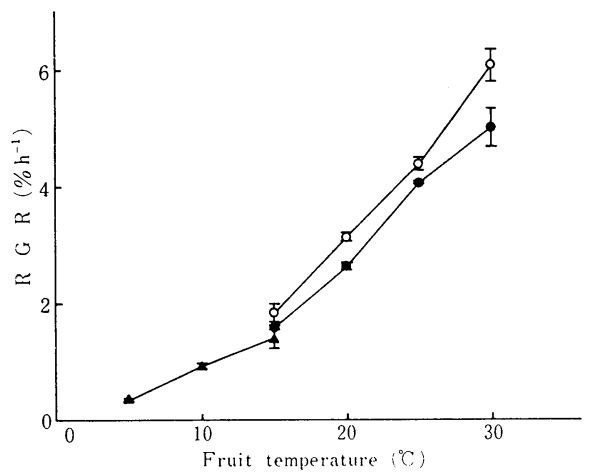

Fig. 3. Effect of fruit temperature on daliy mean RGR of cucumber fruit for the first day of temperature treatment in winter $(\boldsymbol{O}, \boldsymbol{\Delta})$ and in spring ( $\bigcirc)$. The same symbols belong to a series of treatment undertaken during the same period. Data in winter was cv. Kurume Ochiai $\mathrm{H}$ Gata, those in spring for means of this cultivar and cv. Tokiwa Hikari 3 Go A Gata. Vertical bars indicate $S E$ of means.

Since it appeared likely that the decline of RGR during a period of treatment was related to enlargement of fruit (13), the regression of RGR on fruit temperature $\left(\mathrm{T}^{\circ} \mathrm{C}\right)$ and fruit volume $\left(\mathrm{V} \mathrm{cm}^{3}\right)$ was computed. This is expressed by

$$
\mathrm{RGR}_{m}=a T+b V_{m}+c
$$

where $a, b$ and $c$ are constants. $\mathrm{RGR}_{m}$ and $V_{m}$ are daily means of RGR and $V$. They were computed as follows.

$$
\begin{aligned}
& \mathrm{RGR}_{m}=\left(\ln V_{1}-\ln V_{0}\right) /\left(t_{1}-t_{0}\right) \\
& V_{m}=\left(V_{0}+V_{1}\right) / 2
\end{aligned}
$$

where $V_{0}$ and $V_{1}$ are fruit volumes at times $t_{0}$ and $t_{1}$, respectively. The interval between $t_{0}$ and $t_{1}$ was about 24 hours. As shown in Table 1, the multiple correlation coefficient was so high that the change in RGR could be accounted for by fruit temperature and fruit volume. For the fruits of same size the response of RGR to temperature can be expressed by approximately the same linear relationship. The variation of parameter $b$ due to season or cultivar tended to be greater than that of $a$. The absolute value of $b$ was greater in winter than in spring.

In order to interpret the response of RGR to temperature kinetically, natural logarithm of daily mean RGR at the first day of tre- 
Table 1. Parameters of multiple regression equations of daily mean $\mathrm{RGR}\left(\mathrm{RGR}_{\mathrm{m}} \% \mathrm{~h}^{-1}\right)$ of cucumber fruit to fruit temperature $\left(T^{\circ} \mathrm{C}\right)$ and daily mean volume $\left(V_{m} \mathrm{~cm}^{3}\right)$, i. e., $R G R_{m}=a T+b V_{m}$ $+c$, for two cultivars in two seasons. $R$ is a multiple correlation coefficient. $V_{m}$ and $R_{G} R_{m}$ were for each day of a treatment period during which fruits grew from about 9 to $20 \mathrm{~cm}$ in length.

\begin{tabular}{ccccc}
\hline Cultivar & $\mathrm{a}$ & $\mathrm{b}$ & $\mathrm{c}$ & $\mathrm{R}$ \\
\hline $\begin{array}{c}\text { Kurume Ochiai } \\
\text { H Gata }\end{array}$ & 0.256 & $\begin{array}{c}\text { Winter } \\
-0.0368\end{array}$ & -1.54 & 0.976 \\
$\begin{array}{c}\text { Kurume Ochiai } \\
\quad \text { H Gata }\end{array}$ & 0.267 & $\begin{array}{l}\text { Spring } \\
-0.0123\end{array}$ & -1.92 & 0.991 \\
$\begin{array}{c}\text { Tokiwa Hikari } \\
\text { 3 Go A Gata }\end{array}$ & 0.316 & -0.0157 & -2.97 & 0.977 \\
\hline
\end{tabular}

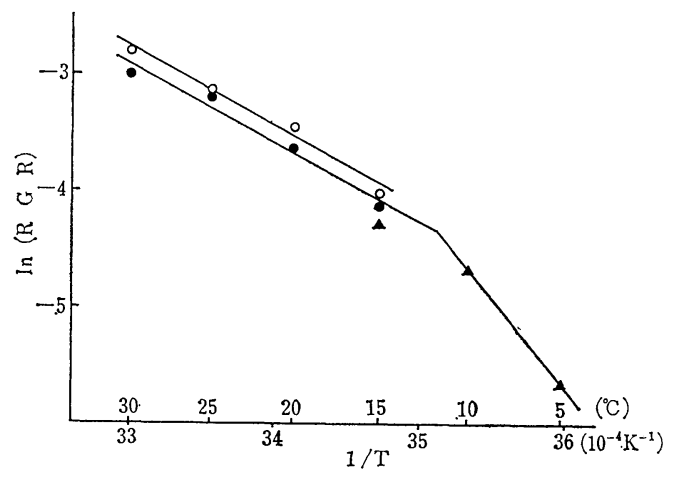

Fig. 4. Natural logarithm of daily mean RGR of cucumber fruit for the first day of temperature treatment plotted against reciprocal of absolute temperature $\left(1 / \mathrm{T} \mathrm{K}^{-1}\right)$ of fruit in winter

A) and in spring ( $\bigcirc)$. The same symbols belong to a series of treatment undertaken during the same period. Data in winter were for cv. Kurume Ochiai H Gata, those in spring for means of this cultivar and cv. Tokiwa Hikari 3 Go A Gata.

atment was plotted against the reciprocal of abso lute temperature (Fig. 4). This gave an approximately straight line with a break point near $12^{\circ} \mathrm{C}$. From the slope of the lines, the $Q_{10}$ at each temperature was estimated follo wing the method of Kemp and Blacklow (9) (eq. (3)), in that when a line was expressed as

$$
\text { ln }(\mathrm{RGR})=A-B / T_{a b s}
$$

the $Q_{10}$ was given by

$$
Q_{10}=\exp \left(10 \cdot B / T_{a b s}{ }^{2}\right)
$$

where $A$ and $B$ are constants and $T_{a b s}$ is absolute temperature. In spite of RGR being considerably different between seasons, $Q_{10} s$ between $15^{\circ}$ and $30^{\circ} \mathrm{C}$ were about the
Table 2. $Q_{10}$ of daily mean RGR for the first day of temperature treatment in cucumber fruit in two seasons estimated follwing the method of Kemp and Blacklow (9). Estimations in winter were made for cv. Kurume Ochiai H Gata, those in spring for means of this cultivar and cv. Tokiwa Hikari 3 Go A Gata.

\begin{tabular}{ccccccc}
$\begin{array}{c}\text { Temperature } \\
\left({ }^{\circ} \mathrm{C}\right)\end{array}$ & 5 & 10 & 15 & 20 & 25 & 30 \\
\hline Winter & 7.32 & 6.82 & 2.26 & 2.20 & 2.14 & 2.09 \\
Spring & & & 2.29 & 2.23 & 2.17 & 2.11 \\
\hline
\end{tabular}

same, i.e., about 2. Between $5^{\circ}$ and $10^{\circ} \mathrm{C}$ the $Q_{10}$ was much higher (Table 2).

On cloudy days, RGR was lower than on fine days, even if the temperature was the same (data not shown).

Specific gravity and percent dry weight of fruits were determined at the end of treatments. They varied among fruits but both tended to decline as the fruits became larger. If compared on a fresh weight basis, the specific gravity of fruits at $30^{\circ} \mathrm{C}$ tended to be lower than at the lower temperatures (data not shown).

\section{Discussion}

In analysing the effect of fruit temperature on fruit growth, we chose RGR instead of GR as a growth parameter for the following reasons ; (1) RGR is a variable of a logistic or Gompertz equation which could be fitted well to the growth curve of the early stage of cucumber fruit(13), and (2) in this experiment, as well as in our previous paper (13), variation in replication of $R G R$ was smaller than of GR. In addition, since RGR is growth rate of unit volume, it may be better than GR for comparing growth activity of fruits of variable size.

On fine days, when there should have been a sufficient supply of carbon to fruit, there was good regression of RGR on fruit temperature and fruit volume (Table 1, eq. (1). This is consistent with the results from tomato fruits reported by Walker and Ho $(15,16)$. Eq. (1) means that RGR is related linearly to fruit temperature if fruits are of equal volume. This relationship is seen in Fig. 3, where the volume of fruits was still about the same, since the fruits had 
only been treated for one day.

If fruit volume is equal, GR should change in proportion to $R G R$, and a linear relation. ship of GR with fruit temperature may be derived from that of RGR. Such a linear response of GR to temperature has been reported for leaf length of wheat(3) and barley(2) and fruit length of pea(7). A curvilinear temperature response has also been reported for GR of leaf length in wheat (9) and $\operatorname{corn}(17)$. In this experiment, if RGRs were not made for the first measurement but for means of the measurements over a treatment period, a curvilinear relationship which tended to be flat at the higher temperature range (data not shown) was obtained. This is probably because a mean RGR includes the effect of fruit volume at the time of measurement so that the relationship between RGR and temperature is disturbed.

Eq. (1) also shows that RGR was negatively correlated to fruit volume in fruits at the same temperature. Therefore, the more rapid decline of RGR at the higher temperature (Fig. 2 c) was due to a more rapid increase in volume.

In greenhouse grown cucumbers, the temperature during the early half of the night is often maintained at a relatively higher level than in the latter half in order to enhance the translocation of assimilates. This means that consumption of carbon by respiration is reduced and the cost of heating is reduced(14). According to our results, the effect of a higher temperature was to increase the demand of the fruits for assimilates, rather than to enhance the overall rate of translocation within the whole plant.

At about $5^{\circ} \mathrm{C}$, RGR of fruit was almost zero. This is consistent with the fact that net export of carbon was observed at $5^{\circ} \mathrm{C}$ in tomato fruits(16). An Arrhenius plot of RGR showed a break point near $12^{\circ} \mathrm{C}$. It is reported that an Arrhenius plot of the respiration rate of harvested cucumber fruits has a break point between $9^{\circ}$ and $12^{\circ} \mathrm{C}(12)$, at which temperatures phase transition of the membrane occured $(11,12)$. Hence a change in the physical state of membranes or enzymes may be related to the cessation of growth in fruits on the vine.

Dry weight of fruit was almost proportional to either the fresh weight or the volume (13). By neglecting loss of carbon by respiration, carbon import to fruit results in an increase in dry matter. A proportional relationship between fresh weight and dry weight indicates a proportional import of carbon and water. The carbon import, presumably accompanied by water, unloaded from the phloem will be balanced by water inflow from the xylem. This means that change in fresh weight may be under the influence of the import of both carbon and water.

Between $15^{\circ}$ and $30^{\circ} \mathrm{C} Q_{10}$ of $\mathrm{RGR}$ was about 2 both in spring and winter. However, RGR was influenced by the growing season and the weather, even when fruits were at the same temperature, as shown by the difference in coefficient $\mathrm{A}$ in eq. (2). It is important to note that seasonal differences in RGR were observed even in the fruits at a low fruit temperature of $15^{\circ} \mathrm{C}$, or in those of a small size which were regarded as having a weak demand for assimilates. This fact seems to contradict the assumption that cucumber plants which have a restricted fruit load can supply enough assimilates to fruit to satisfy the demand under any conditions. The explanation may be as follows.

In eq. (2), coefficient $\mathrm{A}$ is not directly related to fruit condition, which is a function of fruit temperature, and gives a proportionality constant, $e^{A}$, of RGR. Thus it is a parameter which is related to the rate of fruit growth but which is determined by some factors other than fruit condition. The carbon translocation rate in the plant is one such possible factor. According to the results of this experiment, however, RGR was more likely to be controlled by carbon demand, determined by fruit temperature, than by translocation rate. Therefore the translocation rate alone was regarded as being inadequate. It will be noted here that the rate of carbon translocation is the product of flux rate and the carbon concentra- 
tion of phloem sap. Thus the carbon concentration of phloem sap is another possible factor. Ho(5) reported a high correlation between the carbon export rate from a leaf and the mean sucrose concentration of the leaf. This is consistent with our view. In this context, it is suggested that the decline in RGR in winter or on cloudy days is caused by a decreased concentration of carbon in the phloem sap, while the rate of influx of sap is determined by fruit condition.

\section{Acknowledgment}

We wish to thank Prof. M. Iwata for his critical reading of this manuscript.

\section{Literature Cited}

1. Charles-EDWARdS, D. A. and L. C. Ho. 1975. Translocation and carbon metabolism in tomato leaves. Ann. Bot. $40: 387-389$.

2. Gallagher, J. N. and P. V. Biscoe. 1979. Field studies of cereal leaf growth. III. Barley leaf extension in relation to temperature, irradiance and water potential. J. Exp. Bot. $30: 645-655$.

3. Gallagher, J. N., P. V. BisCoE and J. S. WALLACE. 1979. Field studies of cereal leaf growth. IV. Winter wheat leaf extension in relation to temperature and leaf water status. J. Exp. Bot. 30:657-668.

4. GEIGER, D. R. 1966. Effect of sink region cooling on translocation of photosynthate. Plant Physiol. 41 : 1667-1672.

5. Ho, L. C. 1976. The relationship between the rates of carbon transport and photosynthesis in tomato leaves. J. Exp. Bot. $27: 87-97$.

6. Ho, L.C. 1977. Effect of $\mathrm{CO}_{2}$ enrichment on the rates of photosynthesis and translocation of tomato leaves. Ann. appl. Biol. $87: 191-200$.

7. Hole, C. C. and P. A. SCotT. 1984. Pea fruit extension rate. I. Effect of light, dark and temperature in controlled environment. J. Exp. Bot. $35: 790-802$.

8. HORI, Y. 1983. Translocation of photosynthates in tomato plants. J. Japan. Soc. Hort. Sci. 52:113-115. (In Japanese)

9. KEMP, D. R. and W. M. BLACKLOW. 1980. Diurnal extension rates of wheat leaves in relation to temperatures and carbohydrate concentrations of the extension zone. J. Exp. Bot. $31: 821-828$.

10. Link, A. J. and C. A. SWANSON. 1960. A study of several factors affecting the distribution of phosphorus-32 from the leaves of Pisum sativum. Plant and Soil $12: 57-68$.

11. LyONS, J. M. 1973. Chilling injury in plant. Ann. Rev. Plant Physiol. 24 : 445-466.

12. LYONS, J. M. and J. K. RAISON. 1970. Oxidative activity of mitochondria isolated from plant tissues sensitive and resistant to chilling injury. Plant Physiol. 45:386-389.

13. TAZUKe, A. and R. SAKIYAMA. 1984. Growth analysis of cucumber fruits on vine by use of the dimensions of fruit shape. J. Japan. Soc. Hort. Sci. 53:30-37. (In Japanese with English summary)

14. TOKI, T. 1970. Physiological studies on optimal environment in growing of the vegetable crops under the glass- and plastic-houses. 1. Temperature analysis for growing cucumber. Bull. Chiba Agric. Exp. Stn. 10:6272. (In Japanese with English summary)

15. Walker, A. J. and L. C. Ho. 1977 a. Carbon translocation in the tomato: Carbon import and fruit growth. Ann. Bot. 41:813-824.

16. WALKER, A. J. and L. C. Ho. 1977 b. Carbon translocation in the tomato: Effects of fruit temperature on carbon metabolism and rate of translocation. Ann. Bot. $41: 825-832$.

17. WATTS, W. R. 1972. Leaf extension in Zea mays. II. Leaf extension in response to independent variation of the temperature of the apical meristem, of the air around the leaves and of the root-zone. J. Exp. Bot. $23: 713-721$. 


\title{
キュウリ果実の生長に及ぼす果実温度の影響 \\ 田附 明夫・崎山 亮三 \\ 東京大学農学部 113 東京都文京区弥生
}

\begin{abstract}
摘 要
1. ガラス室で栽培したキュウリの幼果を植物体に付 けたまま果実チェンバーに入れ，果実周囲の温度を5〜 $30^{\circ} \mathrm{C}$ の一定温度とする処理を行い，果実温度が果実の 体積生長に及洔す影響を調べた。

2. 果実体積の相対生長率 (RGR) は約 $5^{\circ} \mathrm{C}$ で 0 と なり，高温ほど高い值となった，RGR の果実温度と果 実体積に対する重回㷌を各栽培時期について品種別に計 算すると，いずれも重相関係数が高かった．RGR は果 実温度及び果実体積とそれぞれ正，負の偏相関を有し た．その重回帰式は体積が等しい果実では，RGR が果 実温度に対してほぼ直線的に関係することを示した。し 点を持つ直線で表され，果実生長がこの温度を境に質的 に異なる可能性が示唆された。

3. RGR の $\mathrm{Q}_{10}$ は $15 \sim 30^{\circ} \mathrm{C}$ の範囲では季節にかか わらず約 2 であったが, 春の RGR は冬の值より, その 範囲のいずれの温度においても高かった，これらの結果 を説明するため, RGR の季節間差は果実に流入する師 部液の糖濃度の季節間差によってもたらされ，また，果 実温度は果実に対する師部液の流入速度を決定するとい ら仮説を示した.

4. 供試した 2 品種間で RGR の温度反応には差が認 められなかった。
\end{abstract} かし， RGR のアレニウス・プロットは $12^{\circ} \mathrm{C}$ 付近に屈曲 